\begin{tabular}{llr}
\hline Jurnal Pendidikan Dasar Perkhasa & \\
http://jurnal.stkippersada.ac.id/jurnal/index.php/JPDP/ & P-ISSN 2461-078X \\
E-ISSN 2654-783X & & DoI : 10.31932/jpdp.v5i2.476 \\
\hline JPDP & JPDP $5(2)(2019)$ 133-144 & (2) \\
\hline
\end{tabular}

\title{
PENERAPAN MEDIA MINIATUR UNTUK MENINGKATKAN PARTISIPASI SISWA KELAS IV TEMA 8 SUB TEMA 1 SDN 2 PERMANU PAKISAJI MALANG TAHUN AJARAN 2018/2019
}

\author{
Tri Widyawati*1, Diana Kusumaningrum² \\ 12Program Studi PGSD Universitas Islam Raden Rahmat Malang \\ Diterima: 14 September 2019. Dipublikasi: 30 Oktober 2019.
}

\begin{abstract}
This research needs to be done because of the lack of motivation and student interest in thematic learning, resulting in the participation of students is still partly low. This can be seen from the indicators of student participation on October 8, 2018, namely students who actively participated in discussions as many as 11 students (34.42\%), students who asked questions as many as 7 students (20\%), students who presented answers to the exercise questions were 6 students (17.14\%). This study aims to determine the results of efforts to increase student participation through miniature media on thematic subjects, theme 8 sub themes 1 in SD Negeri 2 Permanu Pakisaji Malang. This type of research is classroom action research. The method used in data analysis is descriptive qualitative analysis method. This study uses miniature media which will be able to foster students' thinking patterns in terms of applying touch, sight and memory of students. The subjects of the study were students in class IV SD Negeri 2 Permanu Pakisaji Malang in the academic year 2018/2019 with a total of 35 students. Research is carried out in two cycles, in each cycle planning, action, observation and reflection are carried out. Data collection techniques in this study use the observation sheet of student participation and observation sheet of the success of the teacher's actions. The results showed that the application of miniature media could increase student participation in thematic learning, especially thematic subjects grade IV SDN 2 Permanu Pakisaji Malang. This can be seen from the increase in learning participation in each cycle. The score in the first cycle shows that $40 \%$ of students who reach the active and very active categories have achieved indicators of success. So the learning process must be improved to a maximum of two cycles. Student participation began to be seen in cycle II showing $94 \%$ of students reached the active category and were very active in achieving success indicators. From the data acquisition, the application of miniature media can increase student participation in thematic learning in class IV SDN 2 Permanu Pakisaji Malang.
\end{abstract}

Keywords: Miniature Media, Student Participation, Thematic Learning

Abstrak. Penelitian ini perlu dilakukan karena kurangnya motivasi dan minat siswa terhadap pembelajaran tematik sehingga mengakibatkan partisipasi siswa sebagian masih rendah. Hal ini dapat dilihat dari indikator partisipasi siswa pada tanggal 8 Oktober 2018 yaitu siswa yang berpartisipasi aktif dalam berdiskusi sebanyak 11 siswa (34,42\%), siswa yang mengajukan pertanyaan sebanyak 7 siswa (20\%), siswa yang mempresentasikan jawaban soal latihan sebanyak 6 siswa $(17,14 \%)$. Penelitian ini bertujuan untuk mengetahui hasil upaya peningkatan partisipasi siswa melalui media miniatur pada mata pelajaran tematik, tema 8 sub tema 1 di SD Negeri 2 Permanu Pakisaji Malang. Jenis penelitian yang digunakan adalah penelitian tindakan kelas (classroom action research). Metode yang digunakan dalam analisis data yaitu metode analisis deskriptif kualitatif. Penelitian ini menggunakan media miniatur yang nantinya akan dapat menumbuhkan pola fikir peserta didik dalam hal penerapan daya raba, daya lihat dan daya ingat peserta didik. Subjek dari penelitian adalah peserta didik di kelas IV SD Negeri 2 Permanu Pakisaji Malang tahun akademik 2018/2019 yang berjumlah 35 siswa. Penelitan dilakukan dalam dua 
siklus, dalam setiap siklus dilakukan perencanaan, tindakan, pengamatan dan refleksi. Teknik pengumpulan data dalam penelitian ini menggunaan lembar observasi partisipasi siswa dan lembar observasi keberhasilan tindakan guru. Hasil penelitian menunjukkan bahwa penerapan media miniatur dapat meningkatkan partisipasi siswa pada pembelajaran tematik khususnya mata pelajaran tematik kelas IV SDN 2 Permanu Pakisaji Malang. Hal tersebut dapat dilihat dari adanya peningkatan partisipasi belajar pada setiap siklusnya. Perolehan skor pada siklus I menunjukkan $40 \%$ siswa yang mencapai kategori aktif dan sangat aktif yang mecapai indikator keberhasilan. Sehingga proses pembelajaran harus diperbaiki pada siklus dua secara maksimal. Partisipasi siswa mulai terlihat pada siklus II menunjukkan 94\% siswa mencapai kategori aktif dan sangat aktif mencapi indikator keberhasilan. Dari perolehan data tersebut maka penerapan media miniatur dapat meningkatkan partisipasi siswa pada pembelajaran tematik di kelas IV SDN 2 Permanu Pakisaji Malang.

Kata kunci: Media Miniatur, Partisipasi Siswa, Pembelajaran Tematik 